\title{
Attitudes and opinions of French general practitioners towards tobacco
}

\author{
J-F Tessier, L René, C Nejjari, D Belougne, J Moulin, P Fréour
}

\begin{abstract}
Objective-To assess attitudes and opinions of French general practitioners towards tobacco.

Design-A postal survey in 1991 of a national sample of 4318 French general practitioners using a questionnaire designed by the World Health Organisation and the International Union against $\mathrm{Tu}$ berculosis and Lung Disease (IUATLD) for health professionals.

Results-The mean age of the sample was $41 \pm 9$ years, $80 \%$ of the practitioners were males. The prevalence of smoking was $32 \%$ ( $21 \%$ daily, $11 \%$ occasional). There were more never-smokers among females $(41 \%$ vs $25 \%)$ and more in the age group $<35$ years than in those aged $>45$. Of daily smokers $54 \%$ claimed that they had made at least one attempt to stop smoking but only $32 \%$ expected to have stopped within five years of the survey.
\end{abstract}

Practitioners had a good knowledge of tobacco-related respiratory diseases but underestimated the risk of cardiovascular diseases. Only $37 \%$ (23\% of daily smokers) would counsel a patient to stop smoking if he did not have a smokingrelated illness and did not himself raise the question; $62 \%$ thought they had sufficient knowledge to advise their patients on stopping smoking.

Conclusions-These results, similar to those of the IUATLD worldwide survey of medical students, showed a lower prevalence of smoking in younger compared to older doctors and also demonstrated the influence of personal smoking on the attitude of practitioners towards smoking patients.

(Tobacco Control 1993; 2: 226-30)

\section{Introduction}

During the last few years the Tobacco and Health Committee of the International Union against Tuberculosis and Lung Disease (IUATLD) has initiated, with the help of the World Health Organisation (WHO), a series of surveys on smoking behaviour and attitudes of health professionals, most notably a worldwide study of first- and final-year medical students.

These surveys ${ }^{1-4}$ have shown that in many countries (especially in France) final-year students still lacked knowledge of smokingrelated diseases and did not have a preventive approach to smoking patients. Moreover their attitudes towards smoking problems were much influenced by their personal smoking behaviour. Such deficiencies are important as these future practitioners will be, to quote Richmond and Webster, "in a strategic position" to help patients to stop smoking.

There are few recent data on French general practitioners and tobacco, despite new antitobacco laws and regulations in France. Accordingly we thought it useful to study their attitudes and opinions, as we had done for medical students. With the help of the Ordre National des Médecins, the French cooperative and administrative organisation for doctors, we conducted a survey in 1991 of a sample of general practitioners.

\section{Subjects and methods}

One administrative subdivision (Department) was randomly selected from each of the 22 French administrative Regions. Questionnaires were sent by the Ordre National des Médecins to all general practitioners in each selected Department, a total of 11800 doctors.

The questionnaire, based on the IUATLD and WHO questionnaires for health professionals, ${ }^{2,6}$ covered personal smoking behaviour, the perceived importance of different reasons for stopping smoking, knowledge of tobacco-related diseases, attitudes towards smoking patients; and opinions on preventive measures, including laws and regulations against tobacco.

For organisational and financial reasons, it was not possible to send a reminder to all nonresponders to the first mailing. Instead, a second questionnaire was sent to a random subsample of 1118 non-responders. The 628 responses received from the subsample (response rate: $56 \%$ ) did not differ for any of the items from the 3795 responses (response rate: $32 \%$ ) received from the initial mailing. The total number of questionnaires received was therefore $4423(3795+628)$, giving an overall response rate of $37 \%$. Among these, only 4318 answered the main items concerning age, sex, and smoking behaviour. The remaining 105 were therefore excluded from the analysis.

Statistical comparisons were made using univariate analysis. Differences were evaluated by the Chi-square test. Where ranges are given in the text, they represent $95 \%$ confidence limits.

Smokers were divided into those who smoked daily and those who smoked only 
Table 1 Demographic data

\begin{tabular}{|c|c|c|c|c|}
\hline & \multicolumn{3}{|c|}{ Age (years) } & \multirow[b]{2}{*}{$\begin{array}{l}\text { All practitioners } \\
\quad(n=4318)\end{array}$} \\
\hline & $\begin{aligned} & <35 \\
(n & =1395)\end{aligned}$ & $\begin{array}{c}35-45 \\
(n=1965)\end{array}$ & $\begin{aligned} & >45 \\
(n & =958)\end{aligned}$ & \\
\hline \multicolumn{5}{|l|}{$\operatorname{Sex}(\%)^{\star}$} \\
\hline Male & 65 & 83 & 93 & 80 \\
\hline Female & 35 & 17 & 7 & 20 \\
\hline \multicolumn{5}{|c|}{ Residence (\%) } \\
\hline City & 21 & 19 & 20 & 20 \\
\hline Town & 40 & 41 & 45 & 42 \\
\hline Village & 39 & 40 & 35 & 38 \\
\hline
\end{tabular}

occasionally. Ex-smokers were those who formerly smoked for at least six months but no longer did so. "Never-smokers" is self-explanatory.

\section{Results}

DEMOGRAPHIC DATA (TABLE 1)

Of the 4318 doctors studied, $62 \%$ lived in a city or town, $38 \%$ in a rural area. There was no difference in distribution according to age. The mean age was $41 \pm 9$ years. Overall $80 \%$ were males. Sex distribution varied with age group: there were $7 \%$ of females in those aged more than 45 , and $35 \%$ in those aged 35 or less.

\section{PERSONAL SMOKING STATUS}

Of the 4318 doctors studied, 32\% were smokers (both sexes combined); $21 \%$ daily smokers and $11 \%$ occasional smokers; $40 \%$ were ex-smokers and $28 \%$ never-smokers.

Smoking behaviour differed significantly according to age and sex $(\mathrm{p}<0.001)$ (table 2$)$. There were more daily smokers in males than in females ( $22 \%$ vs $14 \%$ ) and more neversmokers in females ( $41 \%$ vs $25 \%$ ). The pro- portion of never-smokers was higher in young doctors $38 \%$ in males and $47 \%$ in females less than 35 years old) than in older doctors (14\% in males and $35 \%$ in females aged more than 45).

Most smoked filter-tipped cigarettes (62\% among daily smokers). The mean daily cigarette consumption was $15 \pm 10$ in males and $11 \pm 9$ in females.

Overall, $54 \%$ of daily and $48 \%$ of occasional smokers claimed to have made at least one serious attempt to stop smoking. Some $32 \%$ of daily smokers and $81 \%$ of occasional smokers expected to have stopped within five years of the survey.

\section{REASONS FOR PRACTITIONERS NOT SMOKING PERSONALLY (TABLE 3)}

Symptoms, protecting one's own health, self discipline, and setting an example to children were rated the most important reasons for practitioners not smoking personally. As expected, there were few differences between exsmokers and never-smokers but the figures for daily smokers were lower for each potential reason for not smoking.

KNOWLEDGE OF THE DANGERS OF TOBACCO Virtually all practitioners (99\%) strongly agreed that smoking is harmful to health; only 32 practitioners disagreed. There were no significant differences related to gender, age, or even smoking status.

KNOWLEDGE OF CIGARETTE SMOKING AS A

MAJOR CAUSE OF SPECIFIC DISEASES

Table 4 demonstrates good knowledge of the pathogenic effect of cigarette smoking for the

Table 2 Smoking status by gender (male, $M$, and female, $F$ ) and age

\begin{tabular}{|c|c|c|c|c|c|c|c|c|c|c|}
\hline & & & & nokir & & & & & & \\
\hline & Dai & & $O c c$ & ker & & & $\mathrm{Nev}$ & & $\underset{(n}{A l l p r}$ & $\begin{array}{l}\text { oners } \\
\text { 8) }\end{array}$ \\
\hline & $M$ & $F$ & $M$ & $F$ & $M$ & $F$ & $M$ & $F$ & $M$ & $F$ \\
\hline Age $<3$ & 22 & 15 & 13 & 11 & 27 & 28 & 38 & 47 & 19 & 486 \\
\hline Age $36-45^{\star}$ & 24 & 13 & 11 & 8 & 41 & 44 & 23 & 34 & 1631 & 334 \\
\hline Age $>45^{\star}$ & 19 & 13 & 10 & 6 & 56 & 46 & 14 & 35 & 895 & 63 \\
\hline All & 22 & 14 & 11 & 10 & 41 & 35 & 25 & 41 & 3435 & 883 \\
\hline
\end{tabular}

${ }^{\star} \mathrm{p}<0.001$ for males and females

Table 3 "How do you personally assess the importance of the reasons for not smoking yourself?" Percentage of those answering "strongly agree", according to smoking status

\begin{tabular}{|c|c|c|c|c|c|}
\hline & \multicolumn{4}{|c|}{ Smoking status } & \multirow[b]{2}{*}{$\begin{array}{c}\text { All practitioners } \\
(n=4318)\end{array}$} \\
\hline & $\begin{array}{c}\text { Daily smoker } \\
(n=894)\end{array}$ & $\begin{array}{c}\text { Occas smoker } \\
(n=477)\end{array}$ & $\begin{array}{l}\text { Ex-smoker } \\
(n=1725)\end{array}$ & $\begin{array}{c}\text { Never-smoker } \\
(n=1222)\end{array}$ & \\
\hline $\begin{aligned} 1 & \text { Protect your health» }^{\star} \\
3 & \text { Symptoms } \\
4 & \text { Self discipline } \\
4 & \text { Example to patient } \\
5 & \text { Example to children } \\
6 & \text { Discomfort } \\
7 & \text { Example to health work } \\
8 & \text { To save money } \\
9 & \text { Example to adults } \\
10 & \text { Pressure of colleagues }\end{aligned}$ & $\begin{array}{r}51 \\
63 \\
54 \\
26 \\
51 \\
40 \\
7 \\
2 \\
11 \\
5\end{array}$ & $\begin{array}{r}61 \\
71 \\
61 \\
43 \\
64 \\
54 \\
22 \\
2 \\
23 \\
5\end{array}$ & $\begin{array}{r}69 \\
63 \\
69 \\
45 \\
64 \\
46 \\
23 \\
4 \\
25 \\
3\end{array}$ & $\begin{array}{r}74 \\
75 \\
71 \\
55 \\
73 \\
67 \\
34 \\
9 \\
35 \\
7\end{array}$ & $\begin{array}{r}64 \\
66 \\
64 \\
42 \\
63 \\
50 \\
21 \\
4 \\
23 \\
5\end{array}$ \\
\hline
\end{tabular}

$\star_{\mathrm{p}}<0.001$ 
Table 4 Percentage answering "yes" to the question: "Is cigarette smoking a major cause of these diseases?", by age

\begin{tabular}{lccccc}
\hline & \multicolumn{3}{c}{ Age (years) } & \\
\cline { 2 - 4 } & $\begin{array}{c}<35 \\
(n=1395)\end{array}$ & $\begin{array}{c}35-45 \\
(n=1965)\end{array}$ & $\begin{array}{c}>45 \\
(n=958)\end{array}$ & $\begin{array}{c}\text { All practitioners } \\
(n=4318)\end{array}$ \\
\hline Lung cancer & 86 & 85 & 82 & 85 \\
Chronic bronchitis & $799^{\star}$ & 76 & 67 & 75 \\
Oral cancer & 63 & 64 & 59 & 63 \\
Laryngeal cancer & 73 & 73 & 68 & 72 \\
Coronary diseases & $64^{\star}$ & 60 & 53 & 60 \\
Oral leukoplakia & 33 & 58 & 53 & 56 \\
Oral soft tissue lesion & $61^{\star}$ & 66 & 36 & 35 \\
Peripheral vascular disease & 6 & 60 & 50 & 58 \\
Neonatal death & 26 & 25 & 4 & 5 \\
\hline
\end{tabular}

${ }^{\star} \mathrm{p}<0.001$ (age $<35 \mathrm{vs}>45$ ); Non-significant for other items

Table 5 Percentage answering "often" to the questions "In these three situations would you advise patients against smoking? Situation 1: When the patient has symptoms/confirmed diagnosis of smoking-related diseases. Situation 2: When the patient himself raises the question about smoking. Situation 3: When the patient is a smoker who has no symptoms/diagnosis of smoking-related diseases and does not himself raise the question of smoking."

\begin{tabular}{lccccc}
\hline & \multicolumn{5}{c}{ Smoking status } \\
\cline { 2 - 5 } & $\begin{array}{c}\text { Daily smoker } \\
(n=894)\end{array}$ & $\begin{array}{c}\text { Occas smoker } \\
(n=477)\end{array}$ & $\begin{array}{c}\text { Ex-smoker } \\
(n=1725)\end{array}$ & $\begin{array}{c}\text { Never-smoker } \\
(n=1222)\end{array}$ & $\begin{array}{c}\text { All practitioners } \\
(n=4318)\end{array}$ \\
\hline Situation 1 & 99 & 99 & 99 & 99 & 99 \\
Situation 2 & 89 & 92 & 94 & 95 & 93 \\
Situation 3* & 23 & 38 & 39 & 45 & 37 \\
\hline
\end{tabular}

${ }^{\star} \mathrm{p}<0.001$

majority of listed diseases (especially respiratory diseases) but poor knowledge for peripheral vascular disease and bladder cancer.

Young doctors were significantly better informed of the risks for chronic bronchitis, coronary artery disease, and peripheral vascular disease than those over 45 years old ( $p<$ 0.001).

\section{ATTITUDES OF PRACTITIONERS TOWARDS PATIENTS' SMOKING}

In response to the question "In the following situations would you advise patients against smoking?", three situations were proposed, with the practitioner being asked, in reply, to choose between often, sometimes, rarely, or never. Table 5 shows the overall replies for all practitioners, and by smoking status:

Situation 1: In a patient with a smokingrelated condition, all practitioners, even the smokers, would advise against smoking.

Situation 2: When the patient himself raises a question about smoking, a high proportion would advise stopping smoking though the figure was slightly lower for doctors who themselves smoked daily.

Situation 3: When a patient is a smoker who has no symptoms or diagnosis of a smokingrelated disease and does not himself raise the question of smoking, only a small proportion of practitioners would intervene $(37 \%)$. Moreover smokers, especially daily smokers, were significantly less likely than never- and exsmokers to suggest stopping smoking ( $\mathrm{p}<$ 0.001 ). The figure for occasional smokers $(38 \%)$ was significantly less than that for never-smokers $(45 \%)(\mathrm{p}<0.02)$.
FRENCH PRACTITIONERS AND THE ANTISMOKING CAMPAIGN

To the question "What is the role of doctors in the antismoking campaign?" practitioners were invited to indicate "the extent to which you agree or disagree with each of the following statements". Nine propositions concerning the attitudes of doctors are listed in table 6 , which shows the percentage answering "strongly agree" by smoking status.

As expected, for some of the statements (notably numbers 2-4) the answers of smokers differed from those of never-smokers, especially regarding doctors' exemplar role $(\mathrm{p}<$ 0.001 ).

Only $62 \%$ of practitioners felt they had sufficient knowledge to counsel patients on stopping smoking. There was a significant difference in response according to age (not shown in the table): $71 \%$ among the oldest doctors felt adequately equipped in contrast to $56 \%$ among doctors aged 35 or less $(\mathrm{p}<$ $0.001)$.

DOCTORS' ATTITUDES TOWARDS LAWS FOR CONTROLLING THE TOBACCO PROBLEM

Respondents were asked the following question: "A number of different opinions have been expressed about how to reduce smoking through legislative action, would you agree or disagree with the following opinions?" Table 7 gives the responses for seven items and the percentage who replied "strongly agree" by smoking status. The least support was given to banning tobacco advertising and for increasing tobacco taxation. The latter was supported by only $40 \%$ of daily smokers. 
Table 6 "Indicate the extent to which you agree or disagree with each of the statements." Percentage answering "strongly agree", according to smoking status

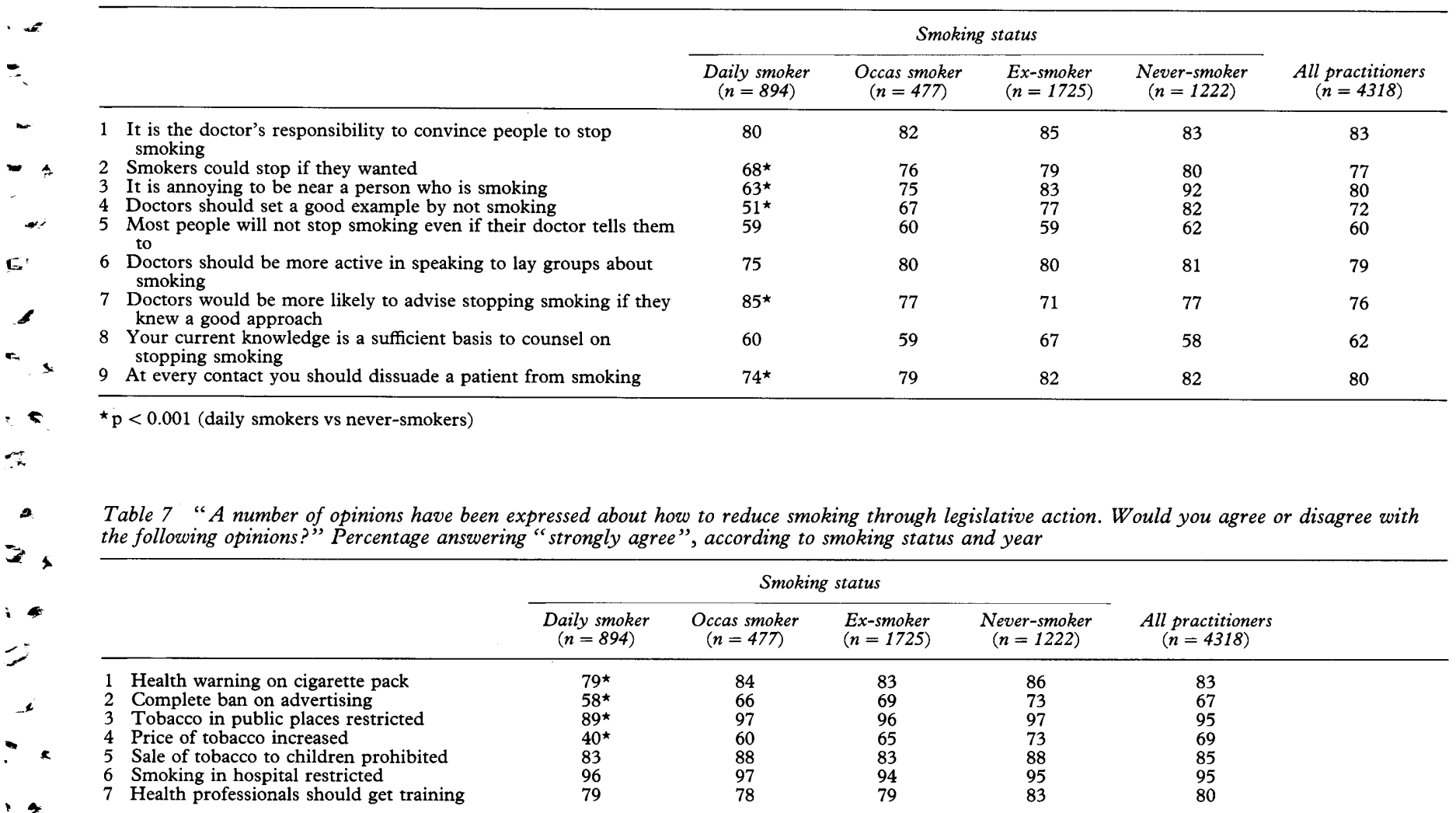

${ }^{\star} \mathrm{p}<0.001$ (daily smokers vs never-smokers)

$f$

\section{Discussion}

How representative was the sample available for analysis? Although it only represents a $37 \%$ overall response rate, the fact that a subsample who responded to a reminder sent to initial non-responders showed no differences in their answers to the questionnaire suggests that our sample may be reasonably representative. In particular, there was no difference in the prevalence of smoking in the first sample and the subsample. Moreover, except for four out of 22 Departments, the average age in the two samples did not differ by more than five years; in those four it was less than ten years. Nevertheless there is a theoretical possibility that initial responders and initial nonresponders are different from persistent nonresponders. If true, smokers might be overrepresented among persistent nonresponders since they might be less likely to fill out a questionnaire about smoking. Thus, any nonresponse bias would likely make our estimate of smoking prevalence an underestimate.

There are no overall data on trends in smoking prevalence in French doctors over the last decade. Figures for doctors in Europe, recently reported by Masironi, ${ }^{7}$ show a decrease since 1966. A similar downward trend has been found in several successive surveys of doctors in southwestern France between 1966 and $1980:^{8} 65 \%$ of smokers in $1966,53 \%$ in 1970 , and $42 \%$ in 1980 ; compared to $32 \%$ in the present survey of the whole of France. Masironi ${ }^{7}$ refers to a number of surveys in different European countries which show a similar decrease. ${ }^{9-13} \mathrm{He}$ also notes similar findings to our own survey: a lack of knowledge about smoking as a cause of specific disease and a hesitancy in advising patients to stop smoking.

Our results suggest a tendency for successive cohorts of doctors to have a lower smoking prevalence. "Never-smokers" comprised $41 \%$ of our youngest age group $(<35)$; this was nearly three times the rate $(16 \%)$ in the oldest group (age $>45$ ). The smoking prevalence, knowledge and attitudes in the young doctors were similar to those in French final-year medical students in the IUATLD study ${ }^{14}$ (table 8). An important factor in influencing the doctor's attitude is clearly his own smoking behaviour (table 3); this, of course, particularly affects doctors' beliefs about their responsibility to serve as an exemplar. ${ }^{15}$

Attitudes and opinions of daily smokers were somewhat different from those of occasional smokers, which were closer to those of ex-smokers and never-smokers. Only $23 \%$ of daily smoking doctors would intervene with a patient in the third Situation (no symptoms and no question from the patient about smoking) vs $38 \%$ of occasional smokers, $39 \%$ of ex-smokers, and $45 \%$ of never-smokers (table 5). The trend was similar for the exemplar role of practitioners (table 6): while $67 \%$ of occasional smokers, $77 \%$ of exsmokers, and $82 \%$ of never-smokers agreed that the doctor should set an example to patients, only $51 \%$ of daily smokers agreed.

In 1991, $99 \%$ of French general practitioners were convinced that smoking was a danger to health, although only $37 \%$ would 
Table 8 Attitudes towards tobacco in young practitioners and final-year French medical students (IUATLD survey)

\begin{tabular}{|c|c|c|}
\hline & $\begin{array}{l}\text { Young practitioners } \\
\quad(n=1395)\end{array}$ & $\begin{array}{l}\text { Final-year } \\
\text { medical students } \\
\quad(n=64)\end{array}$ \\
\hline Mean age (years) & $32 \pm 2$ & 24 \\
\hline $\begin{array}{l}\text { Smoking status }(\%)^{\star} \\
\text { Daily smokers } \\
\text { Occas. smokers } \\
\text { Ex-smokers } \\
\text { Never smokers }\end{array}$ & $\begin{array}{l}20 \\
12 \\
27 \\
41\end{array}$ & $\begin{array}{l}31 \\
13 \\
19 \\
36\end{array}$ \\
\hline $\begin{array}{l}\text { Knowledge of diseases }(\%)^{\star} \\
\text { Lung cancer } \\
\text { Periph vasc dis } \\
\text { Bladder cancer }\end{array}$ & $\begin{array}{l}86 \\
61 \\
26\end{array}$ & $\begin{array}{l}94 \\
72 \\
23\end{array}$ \\
\hline $\begin{array}{l}\text { Advising patients to stop } \\
\text { Situation } 3^{\star \star}\end{array}$ & 35 & 33 \\
\hline $\begin{array}{l}\text { Knowledge sufficient to advise patients } \\
\text { (strongly agree) })^{\star \star \star}\end{array}$ & 53 & 34 \\
\hline
\end{tabular}

$\star$ Non-significant.

$\star \star$ Situation 3: When the patient is a smoker who has no symptoms/diagnosis of smokingrelated diseases and does not himself raise the question of smoking.

$\star \star \star \mathrm{p}<0.008$ smoking behaviour and on their approach to smoking patients. We hope that the present survey will, of itself, have some influence on medical opinion in France and put the accent on needed reforms in physician training during and after medical school.

We are most grateful to all the French general practitioners who took the trouble to participate in the survey.

We acknowledge with gratitude the provision of facilities from the French National Ordre des Médecins, the Département d'Informatique Université de Bordeaux II (Professor $\mathrm{R}$ Salamon) and the technical assistance of Mrs Redon, Assistant Ingénieur of INSERM, Miss MA Audibert, Mrs J Mie and Miss $M$ François for secretarial assistance. We particularly thank Sir John Crofton for help in preparing this report and Mrs EA Pretty for secretarial assistance with the English text.

We are grateful for financial grants from UFR de Santé We are grateful for financial grants from UFR de Sante
Publique, Université of Bordeaux (Professor J Beylot), the European Medical Association, and the Comite de la Gironde contre la Tuberculose et les Maladies Respiratoires (Professor G Courty).

1 Tessier JF, Fréour P, Crofton J, Kombou L. Smoking habits and attitudes of medical students towards smoking and anti-smoking campaigns in fourteen European countries. Eur f Epidemiol 1989; 5: 311-21.

advise a smoking patient to stop smoking if he did not have a smoking-related illness and did not raise the question himself. We found a similar paradox in our worldwide survey of medical students. This attitude may be partly due to doctors concerning themselves primarily with treating their patients rather than protecting them from future disease. Another factor may be some doctors' lack of confidence in their skills as counsellors; $38 \%$ felt they lacked sufficient knowledge about counselling and $76 \%$ believed that doctors would be more likely to advise stopping smoking if they knew a good approach that really worked. In addition, even though $62 \%$ of doctors thought their knowledge was sufficient to counsel on stopping smoking, many of these doctors may not have truly mastered the skills necessary to treat tobacco dependence effectively.

Regarding knowledge of tobacco-related disease, most doctors in our survey were aware of smoking as a major cause of respiratory diseases (lung cancer, laryngeal cancer, chronic bronchitis), but fewer appreciated its importance in cardiovascular disease (coronary artery and peripheral vascular disease) (the questionnaire was designed before the role of smoking was clearly established in stroke), and fewer still in bladder cancer (table 4). Younger doctors were marginally better informed than those over 45.

In France, as in many countries where new laws and regulations have been introduced in recent years, it would be useful to conduct similar surveys on a regular basis, as has been done in the USA. ${ }^{16-19}$ By this means one can assess the impact of legislation, and the changing climate of opinion, on doctors'
Tessier JF, Fréour P, Belougne D, Crofton J. Smoking habits and attitudes of medical students towards smoking and anti-smoking campaigns in nine Asian countries. Int f Epidemiol 1992; 21: 298-304

3 Tessier JF, Fréour P, Nejjari C, Belougne D, Crofton J. Smoking behaviour and attitudes of medical students and Middle Eastern countries. Tobacco Control 1992; 1 : 95-101.

4 Tessier JF, Fréour P, Nejiari C, Belougne D, Crofton JW. Smoking behaviour and attitudes towards smoking of medical students in Australia, Japan, USA, Russia, and medical students in Australia, Japan, USA,

5 Richmond R, Webster J. Evaluation of general practitioners' use of a smoking intervention programme. Int $\mathcal{F}$ Epidemiol $1985 ; 14: 396-40$

6 World Health Organisation. Guidelines for the conduct of tobacco smoking surveys among health professionals. Geneva: WHO, 1984: WHO/SMO, 84, 1. Rundschaumed (Praxis) 1991; 80: 483-5.

8 Fréour P, Gachie JP, Labadie JC, Tessier JF. Les médecins et la lutte anti-tabac dans la pratique courante. Rev Int d'Educ Santé 1980; 23 : 111-6.

9 Robalo-Cordeiro A. Tobacco smoking among the health professionals. Proceedings International Symposium "Tobacco Smoking among the Health Professionals", Venice 30-31 May 1986.

10 Salleras San Marti L. Los medicos y el tabacco. Med Clin 1988; 90: 412-5.

11 Bourke GJ, Wilson-Davis K, Thornes D. Smoking habits of the medical profession in the Republic of Ireland. $A m$ F Public Health 1972; 62: 575-80.

2 Franceschi S, Serraino D, Tramani R, Candiani E. Personal 1986; 15 : 584-5.

13 Adriaanse H, Halfens R, Drop MJ, Reek JC. Physicians' 1985; 85:394-5. français et le tabac. Rev Mal Respir 1988; 5: 589-99.

15 Adriaanse H, van Reek I. Physicians' smoking and its exemplary effect. Scand $\mathcal{F}$ Prim Care 1987; 7:193-6.

16 Fulghum JE, Groover Jr ME, Williams AC, Braatz W. Smoking habits of Florida physicians revisited. $\mathcal{F}$ Fla Med Assoc 1972, 59, 23-8.

17 Garfinkel L. Cigarette smoking among physicians and other health professionals 1959-1972. Cancer 1976; 26: 373-5.

18 Garfinkel L, Stellman SD. Cigarette smoking among physicians, dentists, and nurses. $\mathrm{C} a-A$ Cancer fournal for Physicians 1986; 36: 2-8.

19 Gilpin E, Pierce J, Goodman J, Giovino G, Berry C, Burns D. Trends in physicians' giving advice to stop smoking
- United States, 1974-87. Tobacco Control 1992;1:31-6. towards anti-smoking campaigns: a survey in ten African

7 Masironi R. Smoking habits of European doctors. Schweizhabits and attitudes towards smoking in a sample of physician from the Northeast of Italy. Int $\mathcal{f}$ Epidemiol smoking and health in the Netherlands. NY State $\mathcal{F}$ Med

14 Tessier JF, Fréour P, Crofton J. Les étudiants en médecine 